Nereis. Revista Iberoamericana Interdisciplinar de Métodos, Modelización y Simulación
12

55-69

Universidad Católica de

Valencia San Vicente Mártir
Valencia

(España)

\title{
Essential Oils as Natural Antimicrobial and Antioxidant Products in the Agrifood Industry
}

\author{
Aceites esenciales: productos antimicrobianos y antioxidantes naturales \\ en la industria agroalimentaria
}

Fecha de recepción y aceptación: 24 de febrero de 2020, 2 de marzo de 2020

DOI: $10.46583 /$ nereis_2020.12.585

\section{Dolores Ibáñez ${ }^{1}$, M. Pilar López-Gresa², Purificación Lisón², Ismael Rodrigo², José María Bellés², M. Carmen González-Mas' ${ }^{1}$ y M. Amparo Blázquez ${ }^{1 *}$}

\footnotetext{
${ }^{1}$ Departament de Farmacologia. Facultat de Farmàcia. Universitat de València.

${ }^{2}$ Instituto de Biología Molecular y Celular de Plantas. Universidad Politécnica de Valencia-Consejo Superior de Investigaciones Científicas.

* Correspondencia: Universitat de València. Facultat de Farmàcia. Departament de Farmacologia, Avda. Vicent Andrés Estellés s/n 46100. (Burjassot), Valencia. España.E-mail: amparo.blazquez@uv.es
}

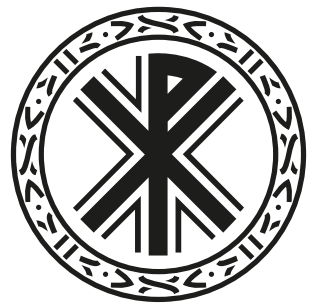

\section{ABSTRACT}

Consumers are aware of the dangers arising from the use of synthetic antioxidants and antimicrobials in the agrifood industry, demanding safer and "greener" alternatives. In this study, the antioxidant activity of commercial essential oils through DPPH method, their antimicrobial effects against the bacterium Pseudomonas syringae and the phytopathogenic fungus Fusarium oxysporum by means of the standardized disk method were determined. Clove along with winter savory, cinnamon and oregano essential oils as well as carvacrol showed the highest antioxidant activity comparable to reference standards. Wintergreen essential oil was the most potent inhibitor against $P$. syringae growth at the highest doses $(20$ and $10 \mu \mathrm{L})$. Oregano essential oil and its main component carvacrol were able to stop the bacterium growth even at the lowest treatment $(1 \mu \mathrm{L})$. Cinnamon, oregano and peppermint essential oils inhibited $F$. oxysporum development at all doses $(20,10$ and $5 \mu \mathrm{L})$ assayed. In general, most of the essential oils displayed more antifungal than antibacterial and antioxidant activities.

KEYWORDS: essential oils, agrifood industry, antioxidant activity, antibacterial activity, antifungal activity.

\section{RESUMEN}

Los consumidores son conscientes del peligro derivado del uso de antioxidantes y antimicrobianos sintéticos en la industria agroalimentaria, demandando alternativas más seguras y ecológicas. En este estudio, se ha determinado la actividad antioxidante de aceites esenciales comerciales mediante el método DPPH y su efecto antimicrobiano frente a la bacteria Pseudomonas syringae y el hongo fitopatógeno Fusarium oxysporum a través del empleo del método estandarizado de disco. Los aceites esenciales de clavo, ajedrea, canela y orégano, así como carvacrol, mostraron 
la máxima actividad antioxidante, comparable a antioxidantes establecidos. El aceite esencial de gaulteria fue el más potente inhibidor del crecimiento de $P$. syringae en las dosis más altas (20 y $10 \mu \mathrm{L}$ ) ensayadas. El aceite esencial de orégano, así como su componente principal carvacrol, detuvieron el crecimiento de la bacteria incluso a la dosis más baja ensayada $(1 \mu \mathrm{L})$. Los aceites esenciales de canela, orégano y menta inhibieron el desarrollo de F. oxysporum en todas las dosis $(20,10$ y $5 \mu \mathrm{L})$ aplicadas. En general, la mayoría de aceites esenciales mostraron más actividad antifúngica que antibacteriana y antioxidante.

PALABRAS CLAVE: Aceites esenciales, industria agroalimentaria, actividad antioxidante, actividad antibacteriana, actividad antifúngica.

\section{INTRODUCTION}

Nowadays, consumers are increasingly aware of the synthetic and harmful products used as antimicrobials and preservatives in the agrifood industry. In response to this, there is an increasing interest in natural products, which could extend shelf-life and avoid pest attack in harvests, the emergence of food spoilage pathogens which cause detrimental effects on the physical characteristics and quality of the products and serious economic losses. In particular, essential oils arise as harmless and "greener" alternatives to the synthetic antioxidant and antimicrobial products, whose safety towards environment and human health is still debated.

Essential oils have demonstrated their usefulness in overcoming storage losses and enhancing shelf-life [1], being often incorporated in films and coatings for food protection. In this respect, oregano essential oil has been included in edible pectin coatings, thus increasing the antioxidant activity in coated tomatoes without negative effects on aroma acceptability of the food [2,3]. Similarly, Zataria multiflora Boiss' essential oil was incorporated into chitosan nanoparticles and its antioxidant activity was evaluated on treated cucumbers, resulting in higher levels of DPPH (2,2-Diphenyl-1-picrylhydrazyl), radical scavenging activity and longer shelf-life during storage [4]. Furthermore, the antioxidant activity of essential oils has been compared with that exerted by commonly used antioxidant standards [5]. In this sense, the antioxidant activity of Xylopia sericea A. St.-Hil. essential oil was evaluated by DPPH scavenging, ferric reduction antioxidant power (FRAP), $\beta$-carotene/linoleic acid bleaching and phosphomolybdenum and thiobarbituric acid-reactive substance (TBARS) assays, showing a higher antioxidant effect ( $80 \%$ of inhibition) in the TBARS assays as compared to BHT (13.7\% of inhibition) [6]. Likewise, the essential oil of other species such as Lantana camara L. showed better radical scavenging power than quercetin, ascorbic acid and BHT [7].

On the other hand, the broad spectrum and potent antimicrobial activity of certain essential oils has already been highlighted [8]. Specifically, eucalyptus (Eucalyptus globulus L.), peppermint (Mentha $\mathrm{x}$ piperita L.) and rose-scented geranium (Pelargonium graveolens L'Hér) essential oils are some examples exhibiting antimicrobial efficiency in the control of pre- and post-harvest rot. They have also shown a remarkable in vitro antimicrobial effect against Gram positive food-spoiling bacteria, such as Bacillus subtilis and Staphylococcus aureus, as well as against fungi and yeasts like Aspergillus flavus, A. niger, Mucor spp., Fusarium oxysporum and Candida albicans. This activity is especially noticeable in vapour phase, thus being suitable alternatives for use in the food industry 
as natural antimicrobial agents [9-11]. Many other essential oils like those obtained from Z. multiflora, Thymus vulgaris L. and T. kotschyanus Boiss. \& Hohen. displayed antimicrobial activity that completely inhibited the growth of the phytopathogenic fungi Pythium apanidermatum, Rhizoctonia solani, F. graminearum and Sclerotinia sclerotiorum at $200 \mu \mathrm{L} / \mathrm{L}$ [12]; Thuja occidentalis essential oil inhibited the growth of the most detrimental plant pathogenic bacteria Agrobacterium tumefaciens and Erwinia carotovora var. carotovora with Minimum Inhibitory Concentrations (MIC) values of 400 and $350 \mathrm{mg} / \mathrm{L}$, while Artemisia monosperma Delile essential oil showed effective concentrations $\left(\mathrm{EC}_{50}\right)$ values between $106-148 \mathrm{mg} / \mathrm{L}$ against the phyopathogenic fungi Alternaria alternata, Botrytis cinerea, F. oxysporum and F. solani [13]. Recently, in vivo antifungal activity of peppermint essential oil has been demonstrated against the spoilage yeasts C. albicans, C. tropicalis, Pichia anomala and especially Saccharomyces cerevisiae in cashew, guava, mango and pineapple juices, affecting the patogen's membrane permeability and potential, enzymatic activity and efflux pump at the minimum dose assayed $(1.875 \mu \mathrm{L} / \mathrm{mL})$ [14]. Finally, other in vivo tests showed significant improvement of potato slices infected with A. niger, Mucor wutungkiao, Penicillium funiculosum and Rhizopus oryzae after the application of $2.0 \mu \mathrm{L} / \mathrm{mL}_{\text {air }}$ of the essential oil obtained from navel orange peel (Citrus sinensis (L.) Osbeck) [15].

All these promising results reinforce the need to delve in the research for antioxidant activity of other commercial essential oils, as well as in their antimicrobial activities against different species. Therefore, the aim of this work is firstly to evaluate the antioxidant activity of selected commercial essential oils using DPPH method and its comparison versus the established antioxidant activity of the natural antioxidants quercetin, ascorbic acid, and the synthetic one BHT. Secondly, this study tries to determine the antibacterial and antifungal capacity of the essential oils by means of the disk diffusion technique on phytopathogenic bacteria and fungi affecting several food crops.

\section{MATERIALS AND METHODS}

\section{Essential Oils and Reference Standard}

Commercial essential oils and reference standard were purchased from Guinama, Planalto Dourado, Pranarôm, Plantis and Carobels (table 1), and stored at $4{ }^{\circ} \mathrm{C}$ until biological studies were carried out.

Table 1. Information about commercial essential oils and reference standard used

\begin{tabular}{cccc}
\hline & Essential oils & & \\
\hline Name & Plant part & Batch & Sell-by-date \\
\hline & Guinama & & \\
\hline Anise (Pimpinella anisum L.) & Ripe dried fruit & 0059857 & $06 / 2017$ \\
Cinnamon (Cinnamomum verum J. Presl) & Leaves & 0072188 & $30 / 11 / 2018$ \\
Clove (Syzygium aromaticum L. Merr. \& Perry) & Leaves & 0065709 & $22 / 08 / 2018$ \\
Eucalypt (Eucalyptus globulus Labill.) & Leaves \& stems & 0065901 & $28 / 02 / 2019$ \\
Marjoram (Origanum majorana L.) & Leaves \& flowers & 0042773 & $13 / 11 / 2016$
\end{tabular}




\begin{tabular}{|c|c|c|c|}
\hline \multicolumn{4}{|c|}{ Essential oils } \\
\hline Name & Plant part & Batch & Sell-by-date \\
\hline \multicolumn{4}{|c|}{ Guinama } \\
\hline Oregano (Origanum vulgare L.) & Flowers & 0042451 & $31 / 05 / 2016$ \\
\hline Peppermint (Mentha piperita L.) & Leaves & 0058567 & $25 / 11 / 2017$ \\
\hline Rosemary (Rosmarinus officinalis L.) & Leaves & 0037337 & $30 / 04 / 2016$ \\
\hline Scots pine (Pinus sylvestris L.) & Needles & 0065144 & $08 / 08 / 2018$ \\
\hline Tea tree (Melaleuca alternifolia Maiden \& Betche ex Cheel) & Leaves & 0051451 & $30 / 09 / 2019$ \\
\hline Winter savory (Satureja montana L.) & Whole plant & 0054366 & $18 / 02 / 2017$ \\
\hline \multicolumn{4}{|c|}{ Planalto Dourado } \\
\hline Spanish marjoram (Thymus mastichina L.) & Leaves \& Flowers & TM010711 & $07 / 2017$ \\
\hline \multicolumn{4}{|c|}{ Pranarôm } \\
\hline Basil (Ocimum basilicum L. ssp. basilicum) & Flowering top & 0F22144 & $08 / 2020$ \\
\hline Ginger (Zingiber officinale Rosc.) & Rhizome & 0F26093 & $04 / 2022$ \\
\hline Lavender (Lavandula angustifolia Mill.) & Flowers & 0082842 & $30 / 11 / 2020$ \\
\hline Lemon eucalyptus (Eucalyptus citriodora Hook) & Leaves & $0 F 25830$ & $02 / 2022$ \\
\hline Turmeric (Curcuma longa L.) & Root & 0F27683 & $10 / 2021$ \\
\hline Wintergreen (Gaultheria procumbens L.) & Leaves & 0F18989 & $11 / 2020$ \\
\hline \multicolumn{4}{|c|}{ Plantis } \\
\hline Chamomile (Matricaria chamomila L.) & Flowers & 725 & $11 / 2017$ \\
\hline \multicolumn{4}{|c|}{ Carobels } \\
\hline Green tea (Camelia sinensis (L.) Kuntze) & Leaves & 26903 & $09 / 2015$ \\
\hline \multicolumn{4}{|c|}{ Reference standard } \\
\hline Compound & Company & Batch & Sell-by-date \\
\hline Carvacrol & Sigma-Aldrich & MKBN3724V & $01 / 2018$ \\
\hline
\end{tabular}

\section{Antioxidant Assay}

The antioxidant activity of the essential oils was evaluated by the DPPH method with some minor modifications [16]. Briefly, $1 \mathrm{~mL}$ of ethanol was taken as blank and $750 \mu \mathrm{L}$ added to $250 \mu \mathrm{L}$ of 0.5 mM DPPH solution was taken as control $\left(A_{0}\right)$. Reaction mixture $\left(A_{1}\right)$ was prepared by taking $740 \mu \mathrm{L}$ of ethanol mixed with $250 \mu \mathrm{L}$ of $0.5 \mathrm{mM} \mathrm{DPPH}$ and $10 \mu \mathrm{L}$ of essential oils, or reference standard or positive controls. After incubation of the mixture at $25^{\circ} \mathrm{C}$ for $30 \mathrm{~min}$ in the dark, the absorbance at $517 \mathrm{~nm}$ was measured using a Pharmacia Biotech 1000E UV-VIS (Pharmacia Biotech, Piscataway, NJ, USA) spectrophotometer. The results were compared with the positive controls: the natural flavonoid quercetin and the synthetic antioxidant BHT $(0.5,5$ and $25 \mathrm{mM})$, as well as ascorbic acid (1 and $2.5 \mathrm{mM})$. The antioxidant activity (\%) was expressed as percentage of inhibition of the DPPH radical by using the following formula:

DPPH scavenging effect $(\%)$ inhibition $=A_{0}-A_{1} / A_{0} \times 100$ 
Where $\mathrm{A}_{0}$ is the absorbance of the control reaction (without test compound), and $\mathrm{A}_{1}$ is the absorbance in presence of all of the essential oils or positive control. All the tests were performed in triplicates and the results were averaged.

\section{Antibacterial Assay}

Pseudomonas syringae pv. tomato $\triangle$ AvrPto was grown during $48 \mathrm{~h}$ at $28{ }^{\circ} \mathrm{C}$ in $\mathrm{LB}$ agar medium with the antibiotics rifampicin $(10 \mathrm{mg} / \mathrm{mL})$, kanamycin $(0.25 \mathrm{mg} / \mathrm{mL})$, and spectinomycin $(2.5 \mathrm{mg} /$ $\mathrm{mL}$ ) according to López Gresa et al., 2017 [17]. When colonies were grown, they were transferred into $15 \mathrm{~mL}$ of King's B liquid medium supplemented with rifampicin and were grown overnight at $28^{\circ} \mathrm{C}$ under continuous stirring $(200 \mathrm{rpm})$.

After $24 \mathrm{~h}, 1 \mathrm{~mL}$ of the bacterial culture was mixed with $14 \mathrm{~mL}$ of King's B agar and poured into Petri dishes. Once solidified, $5 \mathrm{~mm}$-diameter Whatman paper disks (GB005 Blotting Paper, Schleicher $\&$ Schuell) were placed on top of the agar and then different volumes $(1,5,10$ and $20 \mu \mathrm{L})$ of each compound were applied into the disks. Methanol was used as negative control and the antibiotic tetracycline was chosen for the positive one at the concentration of $0.3925 \%(\mathrm{w} / \mathrm{v})$. After incubation during $48 \mathrm{~h}$ at $28{ }^{\circ} \mathrm{C}$, the inhibition zone $(\mathrm{cm})$ was measured using a slide gauge according to the standard disk method.

\section{Antifungal Assay}

Fungicidal activity against the tomato phytopathogenic fungus Fusarium oxysporum f. sp. lycopersici was evaluated in accordance with Hernández, 2018 [18]. The fungus was grown in a liquid sporulation medium during 72 hours at $25^{\circ} \mathrm{C}$ under permanent light and continuous stirring (200 $\mathrm{rpm})$. Then, the solution was filtered through a sterile double gauze to remove the mycelium and the sediment spores were obtained by centrifugation at $3600 \mathrm{rpm}$ for 5 minutes. A solution of purified spores was prepared at a concentration of $10^{5}$ spores $/ \mathrm{mL}$ by using a hemocytometer, mixed in PDA agar medium and distributed in Petri dishes. Once solidified, $5 \mathrm{~mm}$-diameter Whatman paper disks (GB005 Blotting Paper, Schleicher \& Schuell) were placed on top of the agar and then different volumes $(1,5,10$ and $20 \mu \mathrm{L})$ of each compound were applied into the disks. Methanol was used as negative control and the fungicide tebuconazole was chosen for the positive one at the concentration of $0.3925 \%(\mathrm{w} / \mathrm{v})$. After incubation of $72 \mathrm{~h} \mathrm{C}$ in darkness at $28{ }^{\circ} \mathrm{C}$, the inhibition zone $(\mathrm{cm})$ was measured using a slide gauge according to the standard disk method.

\section{Statistics}

Experiments were performed in vitro with three replicates. Data were subjected to statistical analysis using a Kruskal-Wallis test (non-parametric test equivalent to the one-way ANOVA). Different letters indicate significant differences $(p<0.05)$ between the essential oils at the same dose. The IBM SPSS v.19 package was used for all the statistical analyses. 


\section{RESULTS AND DISCUSSION}

\section{Antioxidant Activity of Essential Oils}

The antioxidant properties of certain essential oils through different methods have been established [19]. In this study, the ability of 21 essential oils to donate hydrogen atoms or electrons was evaluated spectrophotometrically by DPPH method.

The results were compared with those obtained using the standards quercetin, BHT and ascorbic acid at different concentrations to estimate the antioxidant potency (figure 1).

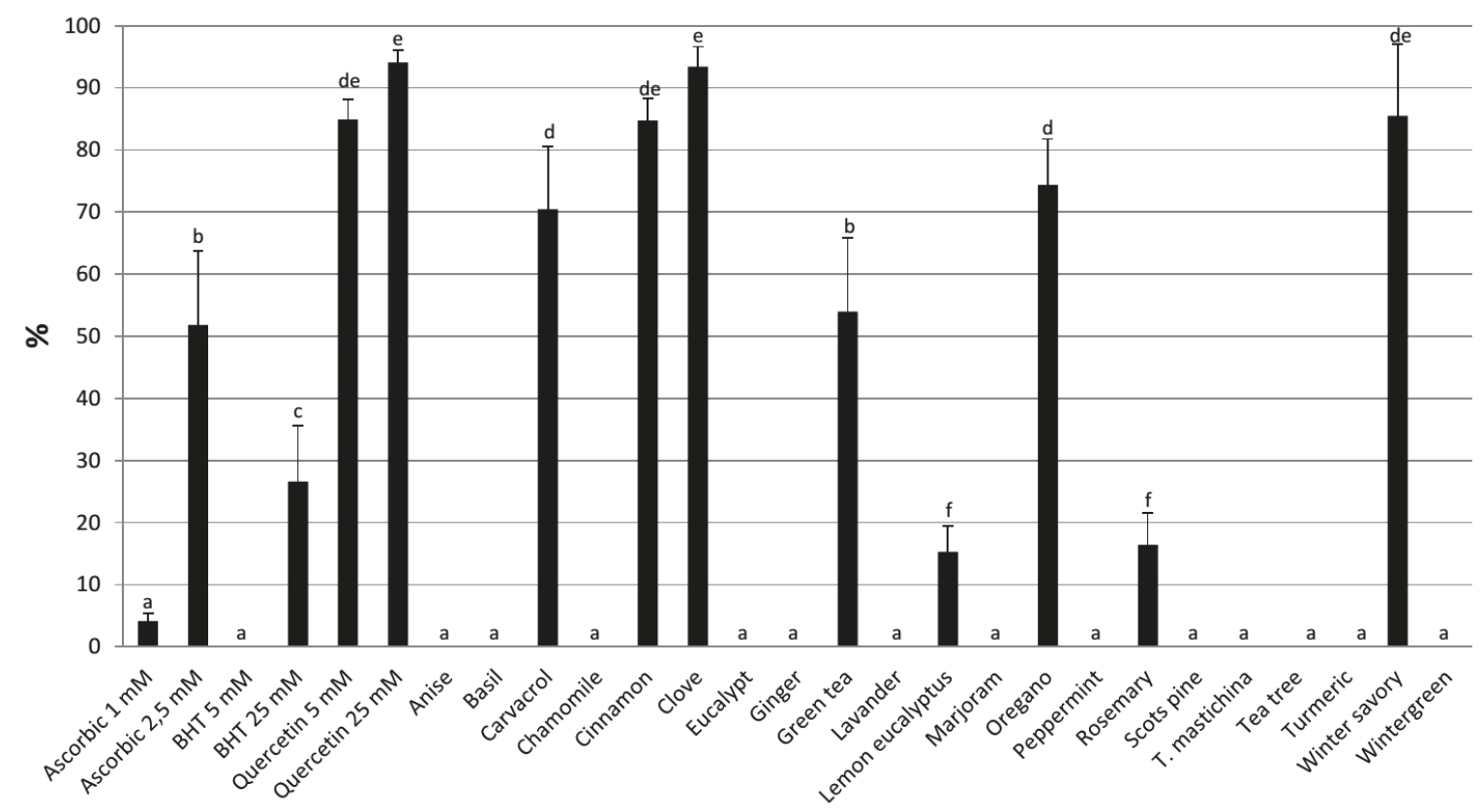

Fig. 1. Antioxidant activity of essential oils studied compared to the standards quercetin, ascorbic acid and BHT. A Kruskal-Wallis analysis was performed and different letters indicate significant differences $(p<0.05)$ between essential oils.

Outstandingly, as little as $10 \mu \mathrm{L}$ of clove essential oil were able to reduce the DPPH reagent in 93.4 \%, being the essential oil with the highest antioxidant activity of all the assayed. Indeed, this result was comparable to the most potent antioxidant reference, quercetin $(94.11 \%)$ at $25 \mathrm{mM}$. The fact that clove essential oil had analogous antioxidant activity to quercetin is especially interesting, as this natural flavonoid is considered to be a powerful free radical scavenger, even more potent than others such as curcumin, commonly used in foods and widely-known for its many beneficial effects on health [20-22]. In previous studies, clove essential oil also displayed the highest percentage of inhibition of DPPH radical, above other essential oils like oregano, thyme, rosemary and sage [23], and even higher than the combinations of them [24]. Furthermore, clove essential oil not only showed 
DPPH radical reduction, but also worked on ABTS (2,2'-azino-bis(3-ethylbenzthiazoline-6-sulfonic acid) and superoxide anion, besides hydrogen peroxide scavenging, and metal chelating activities compared with reference antioxidants, including $\alpha$-BHA, BHT, tocopherol and trolox [25]. As a consequence, clove essential oil represents an alternative, and natural preservative of foodstuff, such as meat products, without affecting organoleptic properties [26]. In fact, clove essential oil incorporated in an active packaging for sausages showed an antioxidant effect at the end of a 15-day refrigeration period without causing significant variations in $\mathrm{pH}$ and water content of the product [27].

In our study, winter savory and cinnamon essential oils also exhibited a relevant antioxidant activity, with values of 85.49 and $84.77 \%$, respectively. Both essential oils have previously shown significant higher persistent antioxidant activity [28]. Winter savory essential oil has already demonstrated a retardation of lipid oxidation in cured meat [29,30]. Cinnamon essential oil revealed remarkable in vitro DPPH radical scavenging activity in comparison to $\alpha$-tocopherol, BHA and BHT mainly attributed to cinnamaldehyde and eugenol $[31,32]$. Due to this activity, cinnamon essential oil has been included in packaging containing pre-harvest and resulting foodstuff with the purpose of extending food shelf-life. In this way, biodegradable polyester nets with cinnamon were observed to maintain the quality of tomatoes during storage [33], and films containing cinnamon and based on carboxymethyl cellulose (CMC)-polyvinyl alcohol (PVA) demonstrated a great improvement of the antioxidant properties for bread preservation [34].

Furthermore, the antioxidant potential of oregano essential oil was compared to that exerted by its main compound, carvacrol. Analogous antioxidant activity was found between both $(74.39 \%$ and $70.49 \%$, respectively), being higher than that obtained by BTH and ascorbic acid. Previous studies also reported a higher activity of oregano as compared to carvacrol probably due to a synergistic effect between the different compounds present in the essential oil [35]. In relation to this, oregano essential oil has been combined with BHT showing a synergistic effect and consequently a higher antioxidant activity, preventing lipid oxidation in food, more specifically sunflower oil [36]. Similar to our findings, oregano essential oil and carvacrol have also demonstrated their remarkable antioxidant effect by other means, such as the chelating effect [37]. Specifically, carvacrol has already been incorporated in materials like gelatin edible films and potato starch nanofibers for its application in food preservation $[38,39]$. Nevertheless, different isolated components of other essential oils have improved the food preservation more than carvacrol, for instance trans-anethole and eugenol [40]. Combined with other components such as thymol, carvacrol has had an additive effect at lower doses but antagonistic at higher concentrations $(2.50 \mathrm{mM})$ [41].

On the other hand, the antioxidant activity of green tea essential oil with cis-methyl dihydrojasmonate (15.82\%) as the main compound [42] was $53.99 \%$, analogous to that displayed by $2.5 \mathrm{mM}$ ascorbic acid with a percentage of $51.83 \%$.

Finally, essential oils from either rosemary -whose main compounds are 1,8-cineole (25.0\%) and camphor $(20.5 \%)$ - or lemon eucalyptus with citronellal as major compound $(88.0 \%)$ showed low DPPH reducing power (16.46 and $15.35 \%$, respectively). These values were higher than those obtained with $1 \mathrm{mM}$ ascorbic acid. Previous studies confirmed the moderate antioxidant activity of rosemary essential oil [43] with a wide range of DPPH radical scavenging activity (8.16-51.80 \%) [44]. Other studies, however, indicated that lemon eucalyptus essential oil exhibited moderate to strong antioxidant activity in terms of TAA, FRAP, $\mathrm{Fe}^{+2}$ chelating, DPPH and $\mathrm{H}_{2} \mathrm{O}_{2}$ scavenging $[45,46]$. 
The other essential oils here studied showed negligible antioxidant activity, such as eucalyptus essential oil with 1,8-cineole as the main compound (76.4\%), whose weak antioxidant capacity has also been reported by other authors [47]. In contrast, other essential oils like wintergreen essential oil with methyl salicylate $(99.60 \%)$ that have shown scarce antioxidant activity in this research, exhibited (having a similar composition, methyl salicylate $96.90 \%$ ) moderate antioxidant activity in DPPH method [48]. Likewise, turmeric essential oil with higher percentage of $\alpha$-turmerone (42.6\%) than ar-turmerone (12.9\%) possessed antioxidant activity using both ABTS and DPPH methods [49] while in our study no antioxidant activity was detected in turmeric essential oil with $\alpha$-turmerone and ar-turmerone values of 14.2 and $38.7 \%$, respectively.

\section{Antimicrobial Activity of Essential Oils}

In this study, antibacterial and antifungal activities of 21 essential oils were evaluated at different doses $(1,5,10$ and $20 \mu \mathrm{L})$ against the Gram-negative bacterium $P$. syringae pv. tomato, the causative agent of the bacterial speck disease [50], and the fungus $F$. oxysporum f. sp. lycopersici, causal agent of the vascular wilt [51], both producing important economical loses on tomato plants (figure 2).

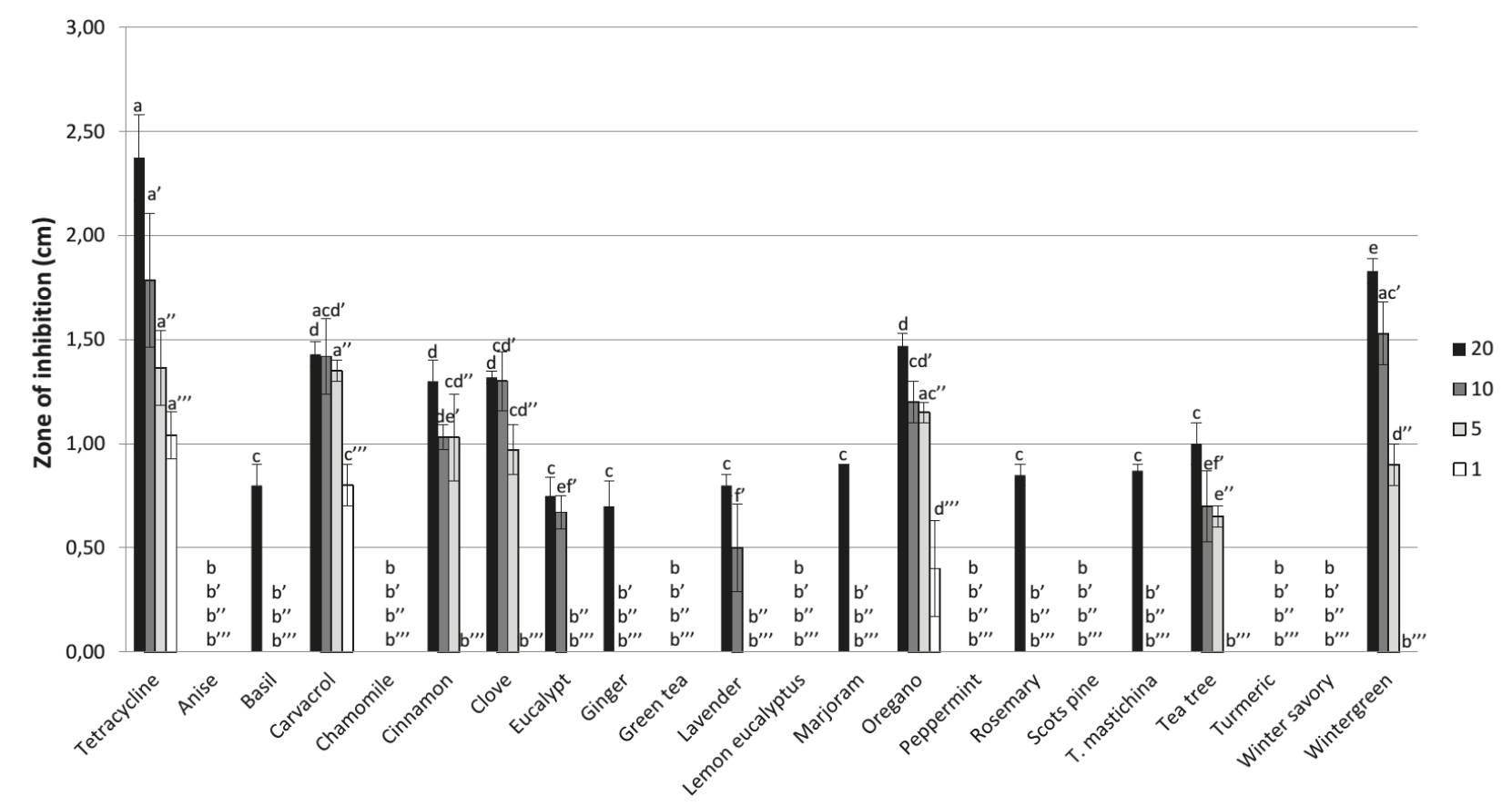

Fig. 2. The inhibition zone $(\mathrm{cm})$ of the $P$. syringae growth by the essential oils at several doses $(1,5,10$ and $20 \mu \mathrm{L})$ as compared to the standard (tetracycline). A Kruskal-Wallis analysis was performed and different letters indicate significant differences $(p<0.05)$ between essential oils at the same dose (same superindex). 
Wintergreen essential oil showed the major values of $P$. syringae growth inhibition at the highest doses (20 and 10) tested. In fact, this essential oil has been previously reported by its broad-spectrum against Gram-positive and Gram-negative food spoiling bacteria and fungi [48].

Carvacrol, the main component of oregano essential oil, also showed antibacterial activity at all of the studied doses $(1.43 \mathrm{~cm}$ at $20 \mu \mathrm{L}, 1.42 \mathrm{~cm}$ at $10 \mu \mathrm{L}, 1.35 \mathrm{~cm}$ at $5 \mu 1$ and $0.80 \mathrm{~cm}$ at $1 \mu \mathrm{L})$. However, in other studies, carvacrol exhibited negligible activity against $P$. syringae in comparison to other components of essential oils, such as eugenol, when it was incorporated in films at doses between 1 and $4 \mathrm{mg} / \mathrm{cm}^{2}$ [52]. Anyway, the antimicrobial properties of carvacrol have been generally confirmed, being considered a natural alternative antimicrobial agent for future application in food preservation [53]. In this sense, oregano essential oil displayed antibacterial effect against $P$. syringae, analogous to its main component carvacrol, achieving an inhibition halo of $0.4 \mathrm{~cm}$ even at $1 \mu \mathrm{L}$. An antibacterial activity against different strains of $P$. syringae had also been described, being stronger than the antibiotic streptomycin [54].

The antibacterial activity of cinnamon and clove essential oils having eugenol as the principal component (56.34 and $89.37 \%$, respectively) was also noticeable and comparable to each other, with no bacterial growth inhibition at the lowest dose assayed $(1 \mu \mathrm{L})$. Several studies have demonstrated that both essential oils have antimicrobial effect against plant pathogenic bacteria [55] and even cinnamon essential oil, which has cinnamaldehyde as the main compound ( $70 \%)$, improved the effectivity and specificity against $P$. syringae, when encapsulated into mesoporous silica nanoparticles (MSNPs), eliminating $99.9 \%$ of the bacterial growth [56].

Similarly, tea tree essential oil, whose antimicrobial properties have been extensively described [57], showed antibacterial activity at the three major doses $(20,10$ and $5 \mu \mathrm{L})$ applied, reaching reduction levels equivalent to half of the tetracycline ones.

Eucalyptus and lavender essential oils only showed antibacterial effect at the highest doses assayed with an inhibition zone of 0.75 and $0.80 \mathrm{~cm}$ at $20 \mu \mathrm{L}$, and 0.67 and $0.50 \mathrm{~cm}$ at $10 \mu \mathrm{L}$, respectively. In previous reports, eucalyptus essential oil also displayed a strong antibacterial effect against P. syringae pv. tomato even at a concentration of $1 \%[58,59]$.

Finally, ginger, basil, rosemary, T. mastichina and marjoram essential oils only exhibited antibacterial activity at the maximum dose $(20 \mu \mathrm{L})$ tested. The reduction of activity of both rosemary and ginger essential oils against $P$. syringae was previously reported [60].

Regarding the antifungal properties, cinnamon, oregano and peppermint essential oils showed the most remarkable antifungal activity against $F$. oxysporum $\mathrm{f}$. sp. lycopersic $i$ with no significant differences between all doses $(20,10$ and $5 \mu \mathrm{L}$ ) assayed (figure 3$)$. Tea tree, ginger and rosemary essential oils displayed similar antifungal activity showing strong inhibition and no significant differences between the two higher doses $(20$ and $10 \mu \mathrm{L})$ applied, but a low activity at $5 \mu \mathrm{L}$. The antifungal activity of cinnamon, oregano, peppermint and rosemary against $F$. oxysporum and other mico- and phytopathogens has been recently corroborated [61,62]. Regarding tea tree essential oil, several studies reported activity against a broad spectrum of phytopathogenic fungi such as Ascochyta rabiei, Colletotrichum lindemuthianum, F. graminearum, F. culmorum, Drechslera avenae, A. radicina, A. dauci and Aspergillus ochraceus $[63,64]$, being the antifungal activity of ginger essential oil against $F$. oxysporum also noticeable at lower doses of only $0.3 \%(\mathrm{v} / \mathrm{v})[65]$. 


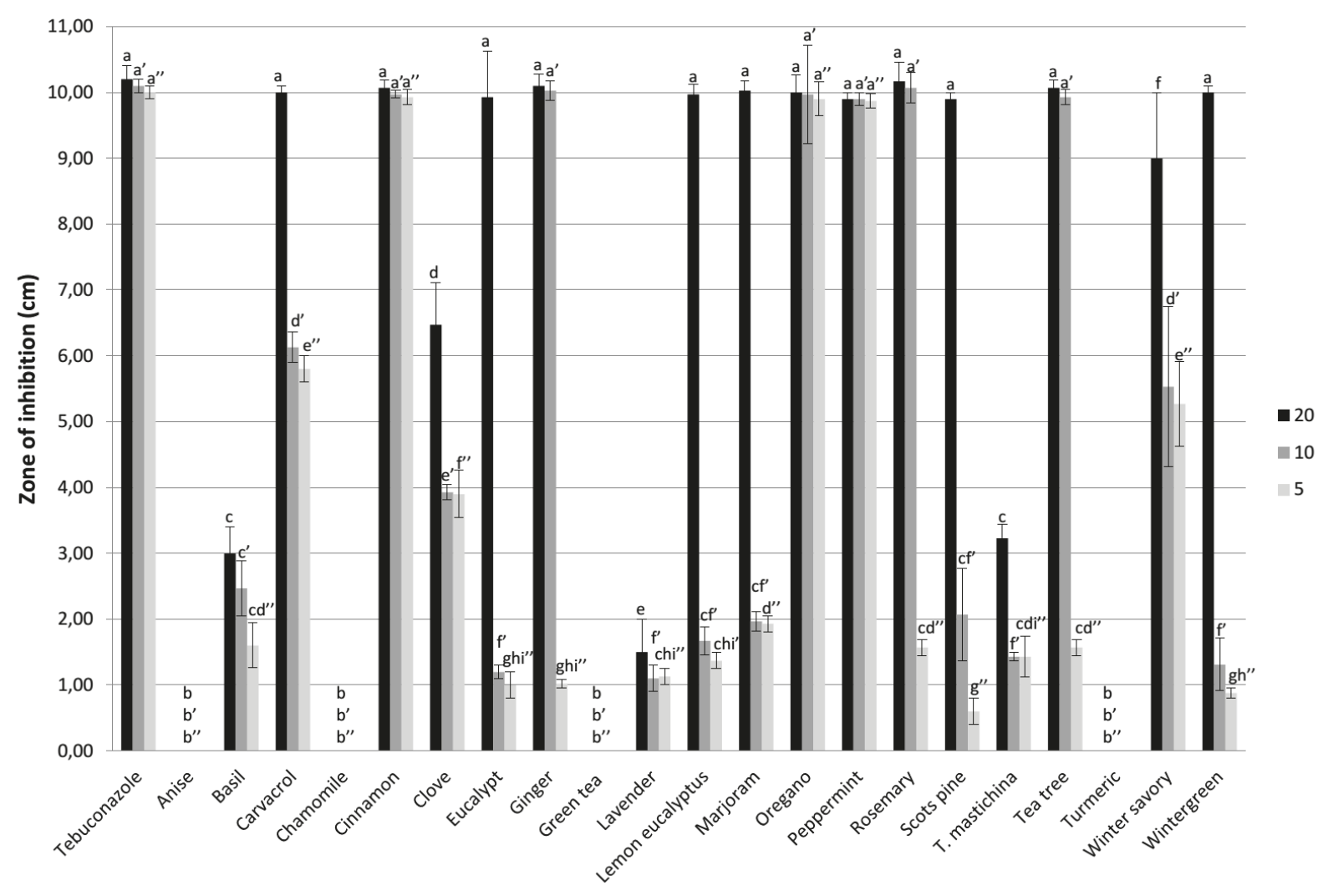

Fig. 3. The inhibition zone $(\mathrm{cm})$ of $F$. oxysporum growth by the essential oils at several doses $(5,10$ and $20 \mu \mathrm{L})$ as compared to the standard (tebuconazole). A Kruskal-Wallis analysis was performed and different letters indicate significant differences $(p<0.05)$ between essential oils at the same dose (same superindex).

On the other hand, eucalyptus, lemon eucalyptus, marjoram, scots pine and wintergreen essential oils, as well as carvacrol, showed similar antifungal activity to that of tebuconazole at $20 \mu \mathrm{L}$, although the fungal growth reduction was low at $10 \mu \mathrm{L}$ and $5 \mu \mathrm{L}$ (figure 3). Otherwise, basil, T. mastichina and lavender essential oils showed low antifungal potential at the three doses assayed. The lack of antifungal activity of lavender essential oil has been previously demonstrated against $F$. oxysporum f. sp. lycopersici, as well as other pathogens of agricultural interest such as A. alternata, A. brassicae, B. spicifera, B. cinerea, R. solani, Cladobotryum mycophilum, C. gloeosporoides, Curvularia hawaiiensis, F. equiseti, F. graminearum, Phytophthora parasitica, Pythium aphanidermatum, $P$. expansum, P. italicum, S. sclerotiorum and Trichoderma aggressivum f. sp. europaeum [61,66]. Finally, anise, chamomile, green tea and turmeric essential oils showed no detectable antifungal activity at neither dose assayed. 


\section{CONCLUSION}

In general, the studied essential oils showed remarkable antioxidant, antibacterial or antifungal activity, being the latter one the most outstanding. Sixteen essential oils exhibited antifungal activity against $F$. oxysporum f. sp. lycopersici with respect to twelve and seven essential oils that showed antibacterial properties against $P$. syringae and antioxidant power, respectively. All the antibacterial essential oils also displayed antifungal activity, indicating that they could be excellent candidates as antimicrobiological agents. Particularly, three essential oils, cinnamon, wintergreen and oregano essential oil, as well as its main component carvacrol, were the most active antimicrobiological natural products.

\section{ACKNOWLEDGEMENT}

The authors thank the group "Señalización y respuesta al estrés biótico" from Instituto de Biología Molecular y Celular de Plantas (IBMCP) for providing the necessary material, protocol and equipment to carry out this study.

\section{LITERATURE CITED}

[1] Prakash B, Kedia A, Mishra PK, Dubey NK. Plant essential oils as food preservatives to control moulds, mycotoxin contamination and oxidative deterioration of agri-food commodities-Potentials and challenges. Food Control. 2015;47(1):381-91.

[2] Rodriguez-Garcia I, Silva-Espinoza BA, Ortega-Ramirez LA, Leyva JM, Siddiqui MW, Cruz-Valenzuela MR et al. Oregano essential oil as an antimicrobial and antioxidant additive in food products. Crit Rev Food Sci Nutr. 2016;56(10):1717-27.

[3] Rodriguez-Garcia I, Cruz-Valenzuela MR, Silva-Espinoza BA, Gonzalez-Aguilar GA, Moctezuma E, Gutierrez-Pacheco MM et al. Oregano (Lippia graveolens) essential oil added within pectin edible coatings prevents fungal decay and increases the antioxidant capacity of treated tomatoes. J Sci Food Agric. 2016;96(11):3772-8.

[4] Mohammadi A, Hashemi M, Hosseini SM. Postharvest treatment of nanochitosan-based coating loaded with Zataria multiflora essential oil improves antioxidant activity and extends shelf-life of cucumber. Innov Food Sci Emerg Technol. 2016;33:580-8.

[5] Brewer MS. Natural antioxidants: sources, compounds, mechanisms of action, and potential applications. Compr Rev Food Sci Food Saf. 2011;10(4):221-47.

[6] Mendes R de F, Pinto N de CC, da Silva JM, da Silva JB, Hermisdorf RC do. S, Fabri RL, et al. The essential oil from the fruits of the Brazilian spice Xylopia sericea A. St.-Hil. presents expressive in-vitro antibacterial and antioxidant activity. J Pharm Pharmacol. 2017;69(3):341-8.

[7] Semdé Z, Koudou J, Figueredo G, Zongo C, Somda KM, Sawadogo/Lingani H, et al. Chemical composition, antioxidant and antimicrobial activities of Lantana camara Linn leaves essential oil from Burkina Faso. GSC Biol Pharm Sci. 2018;5(3):124-35. 
[8] Isman M, Miresmailli S, Machial C. Commercial opportunities for pesticides based on plant essential oils in agriculture, industry and consumer products. Phytochem Rev. 2011;10(2):197204.

[9] Tyagi AK, Malik A. Antimicrobial potential and chemical composition of Eucalyptus globulus oil in liquid and vapour phase against food spoilage microorganisms. Food Chem. 2011;126(1):22835.

[10] Tyagi AK, Malik A. Antimicrobial potential and chemical composition of Mentha piperita oil in liquid and vapour phase against food spoiling microorganisms. Food Control. 2011;22(11):170714.

[11] Boukhatem MN, Kameli A, Saidi F. Essential oil of Algerian rose-scented geranium (Pelargonium graveolens): Chemical composition and antimicrobial activity against food spoilage pathogens. Food Control. 2013;34(1):208-13.

[12] Amini M, Safaie N, Salmani MJ, Shams-Bakhsh M. Antifungal activity of three medicinal plant essential oils against some phytopathogenic fungi. Trakia J Sci. 2012;10(1):1-8.

[13] Badawy MEI, Abdelgaleil SAM. Composition and antimicrobial activity of essential oils isolated from Egyptian plants against plant pathogenic bacteria and fungi. Ind Crops Prod. 2014;52:77682.

[14] Almeida ET da C, de Souza GT, de Sousa Guedes JP, Barbosa IM, de Sousa CP, Castellano LRC et al. Mentha piperita L. essential oil inactivates spoilage yeasts in fruit juices through the perturbation of different physiological functions in yeast cells. Food Microbiol. 2019;82:20-9.

[15] Shi Y, Huang S, He Y, Wu J, Yang Y. Navel orange peel essential oil to control food spoilage molds in potato slices. J Food Prot. 2018;81(9):1496-502.

[16] Plazas M, López-Gresa MP, Vilanova S, Torres C, Hurtado M, Gramazio P, Andújar I, Herráiz FJ, Bellés JM, Prohens J. Diversity and relationships in key traits for functional and apparent quality in a collection of eggplant: fruit phenolics content, antioxidant activity, polyphenol oxidase activity, and browning. J Agric Food Chem. 2013; 61(37):8871-9.

[17] López-Gresa MP, Payá C, Ozáez M, Rodrigo I, Conejero V, Klee H, Bellés JM, Lisón P. A new role for green leaf volatile esters in tomato stomatal defense against Pseudomonas syringe pv. tomato. Front Plant Sci. 2018;18(9):1855.

[18] Hernández Aparicio FJ. Estudio de la respuesta defensiva de plantas de tomate frente a una infección virulenta o avirulenta causada por Fusarium oxysporum f. sp. lycopersici. Trabajo Final de Máster. Universitat Politècnica de València. 2018.

[19] Amorati R, Foti MC, Valgimigli L. Antioxidant activity of essential oils. J Agric Food Chem. 2013;61(46):10835-47.

[20] Xu D, Hu MJ, Wang YQ, Cui YL. Antioxidant activities of Quercetin and its complexes for medicinal applications. Molecules. 2019;24:1123.

[21] Anwar H, Hussain G, Mustafa I. Antioxidants from natural sources. In: Shalaby E, Azzam GM, editors. Antioxidants in foods and its applications. London: IntechOpen; 2018. p. 2-28.

[22] Zhang M, Swarts SG, Yin L, Liu C, Tian Y, Cao Y, et al. Antioxidant properties of Quercetin Adv Exp Med Biol. 2011;701:283-9. 
[23] Viuda-Martos M, Ruiz Navajas Y, Sánchez Zapata E, Fernández-López J, Pérez-Álvarez JA. Antioxidant activity of essential oils of five spice plants widely used in a Mediterranean diet. Flavour Fragr J. 2009;25(1):13-9.

[24] Saricaoglu FT, Turhan S. Antimicrobial activity and antioxidant capacity of thyme, rosemary and clove essential oils and their mixtures. J Innov Sci Eng. 2018;2(1):25-33.

[25] Gülçin I, Elmastaş M, Aboul-Enein HY. Antioxidant activity of clove oil-A powerful antioxidant source. Arab J Chem. 2012;5(4):489-99.

[26] Kumar D, Mehta N, Chatli MK, Kaur G, Malav OP, Kumar P. In-vitro assessment of antimicrobial and antioxidant potential of essential oils from Lemongrass (Cymbopogon citratus), Cinnamon (Cinnamomum verum) and Clove (Syzygium aromaticum). J Anim Res. 2017;7(6):1099105.

[27] Ugalde ML, de Cezaro AM, Vedovatto F, Paroul N, Steffens J, Valduga E, et al. Active starch biopolymeric packaging film for sausages embedded with essential oil of Syzygium aromaticum. J Food Sci Technol. 2017;54(7):2171-5.

[28] Özcan MM, Arslan D. Antioxidant effect of essential oils of rosemary, clove and cinnamon on hazelnut and poppy oils. Food Chem. 2011;129(1):171-4.

[29] Coutinho de Oliveira TL, Malfitano de Carvalho S, de Araújo Soares R, Andrade MA, Cardoso M das G, Ramos EM, et al. Antioxidant effects of Satureja montana L. essential oil on TBARS and color of mortadella-type sausages formulated with different levels of sodium nitrite. LWT Food Sci Technol. 2012;45(2):204-12.

[30] Šojić B, Pavlić B, Tomović V, Ikonić P, Zeković Z, Kocić-Tanackov S, et al. Essential oil versus supercritical fluid extracts of winter savory (Satureja montana L.)-Assessment of the oxidative, microbiological and sensory quality of fresh pork sausages. Food Chem. 2019;287:280-6.

[31] El-Baroty GS, Abd El-Baky HH, Farag RS, Saleh MA. Characterization of antioxidant and antimicrobial compounds of cinnamon and ginger essential oils. African J Biochem Res. 2010;4(6):167-74.

[32] Echegoyen Y, Nerín C. Performance of an active paper based on cinnamon essential oil in mushrooms quality. Food Chem. 2015;170:30-6.

[33] Black-Solis J, Ventura-Aguilar RI, Correa-Pacheco Z, Corona-Rangel ML, Bautista-Baños S. Preharvest use of biodegradable polyester nets added with cinnamon essential oil and the effect on the storage life of tomatoes and the development of Alternaria alternata. Sci Hortic (Amsterdam). 2019;245:65-73.

[34] Fasihi H, Noshirvani N, Hashemi M, Fazilati M, Salavati H, Coma V. Antioxidant and antimicrobial properties of carbohydrate-based films enriched with cinnamon essential oil by Pickering emulsion method. Food Packag Shelf Life. 2019;19:147-54.

[35] Gavaric N, Mozina SS, Kladar N, Bozin B. Chemical profile, antioxidant and antibacterial activity of thyme and oregano essential oils, thymol and carvacrol and their possible synergism. $\mathrm{J}$ Essent Oil-Bearing Plants. 2015;18(4):1013-21.

[36] Olmedo R, Ribotta P, Grosso NR. Decrease of chemical and volatile oxidation indicators using oregano essential oil combined with BHT in sunflower oil under accelerated storage conditions. J Food Sci Technol. 2019;56(5):2522-35. 
[37] Rodrigues Fernandes Ferreira V, Lee Nelson D, Saczk AA, da Silva Felix F, Magalhaex Brandao R, Cardoso M das G. Chelating effect of carvacrol and the oregano essential oil. In: 49th International Symposium on Essential Oils (ISEO2018). 2018:99.

[38] Neira LM, Martucci JF, Stejskal N, Ruseckaite RA. Time-dependent evolution of properties of fish gelatin edible films enriched with carvacrol during storage. Food Hydrocoll. 2019;94(12):30410.

[39] Fonseca LM, Cruxen CE dos S, Bruni GP, Fiorentini ÂM, Zavareze E da R, Lim L-T et al. Development of antimicrobial and antioxidant electrospun soluble potato starch nanofibers loaded with carvacrol. Int J Biol Macromol. 2019;139:9.

[40] Wieczyńska J, Cavoski I. Antimicrobial, antioxidant and sensory features of eugenol, carvacrol and trans-anethole in active packaging for organic ready-to-eat iceberg lettuce. Food Chem. 2018;259:251-60.

[41] Rúa J, del Valle P, de Arriaga D, Fernández-Álvarez L, García-Armesto MR. Combination of carvacrol and thymol: antimicrobial activity against Staphylococcus aureus and antioxidant activity. Foodborne Pathog Dis. 2019;16(9):622-9.

[42] Ibáñez MD, Blázquez MA. Essential oil quality of green tea (Camellia sinensis (L.) Kuntze) in commercial samples. Int J Pharmacogn Phytochem. 2012;31(1):1380-4.

[43] Hendel N, Napoli E, Sarri M, Saija A, Cristani M, Nostro A et al. Essential oil from aerial parts of wild algerian rosemary: screening of chemical composition, antimicrobial and antioxidant activities. J Essent Oil-Bearing Plants. 2019;22(1):1-17.

[44] Kanth MK, Mehta N, Kumar CM, Prakash MO, Kumar P, Wagh RV et al. In-vitro assessment of antimicrobial, antibiofilm and antioxidant potential of essential oil from rosemary (Rosmarinus officinalis L.). J Anim Res. 2018;8(6):989-98.

[45] Poaty B, Lahlah J, Porqueres F, Bouafif H. Composition, antimicrobial and antioxidant activities of seven essential oils from the North American boreal forest. World J Microbiol Biotechnol. 2015;31(6):907-19.

[46] Sing HP, Kaur S, Negi K, Kumari S, Saini V, Batish DR, et al. Assessment of in vitro antioxidant activity of essential oil of Eucalyptus citriodora (lemon-scented Eucalypt; Myrtaceae) and its major constituents. LWT-Food Sci Technol. 2012;48:237-24.

[47] Harkat-Madouri L, Asma B, Madani K, Bey-Ould Si Said Z, Rigou P, Grenier D, et al. Chemical composition, antibacterial and antioxidant activities of essential oil of Eucalyptus globulus from Algeria. Ind Crops Prod. 2015;78:148-53.

[48] Nikolić M, Marković T, Mojović M, Pejin B, Savić A, Perić T et al. Chemical composition and biological activity of Gaultheria procumbens L. essential oil. Ind Crops Prod. 2013;49:561-7.

[49] Brado Avanço G, Dias Ferreira F, Silva Bomfim N, de Souza Rodrigues dos Santos PA, Peralta RM, Brugnari T, et al. Curcuma longa L. essential oil composition, antioxidant effect, and effect on Fusarium verticillioides and fumonisin production. Food Control. 2017;73:806-13.

[50] Uppalapati SR, Ishiga Y, Wangdi T, Urbanczyk-Wochniak E, Ishiga T, Mysore KS et al. Pathogenicity of Pseudomonas syringae pv. tomato on tomato seedlings: Phenotypic and gene expression analyses of the virulence function of coronatine. Mol Plant-Microbe Interact. 2008;21(4):383-95. 
[51] González I, Arias Y, Peteira B. Aspectos generales de la interacción Fusarium oxysporum f. sp. lycopersici-tomate. Rev Protección Veg. 2012;27(1):1-7.

[52] Alkan D, Yemenicioğlu A. Potential application of natural phenolic antimicrobials and edible film technology against bacterial plant pathogens. Food Hydrocoll. 2016;55:1-10.

[53] Nostro A, Papalia T. Antimicrobial activity of carvacrol: Current progress and future prospectives. Recent Pat Antiinfect Drug Discov. 2012;7(1):28-35(8).

[54] Oliva MM, Carezzano ME, Giuliano M, Daghero J, Zygadlo J, Bogino P et al. Antimicrobial activity of essential oils of Thymus vulgaris and Origanum vulgare on phytopathogenic strains isolated from soybean. Plant Biol. 2015;17(3):758-65.

[55] Božik M, Nový P, Klouček P. Chemical composition \& antimicrobial activity of cinnamon, thyme, oregano \& clove essential oils against plant pathogenic bacteria. Acta Univ Agric Silvic Mendelianae Brun. 2017;65(4):1129-34.

[56] Bravo Cadena M, Preston GM, Van der Hoorn RAL, Townley HE, Thompson IP. Species-specific antimicrobial activity of essential oils and enhancement by encapsulation in mesoporous silica nanoparticles. Ind Crops Prod. 2018;122:582-90.

[57] Carson CF, Hammer KA, Riley TV. Melaleuca alternifolia (tea tree) oil: A review of antimicrobial and other medicinal roperties. Clin Microbiol Rev. 2006;19(1):50-62.

[58] Sabir A, El-Khalfi B, Errachidi F, Chemsi I, Serrano A, Soukri A. Evaluation of the potential of some essential oils in biological control against phytopathogenic agent Pseudomonas syringae pv. tomato DC3000 responsible for the tomatoes speck. J Plant Pathol Microbiol. 2017;8(9):420.

[59] Oliveira da Silva É, Martins SJ, Alves E. Essential oils for the control of bacterial speck in tomato crop. African J Agric Res. 2014;9(34):2624-9.

[60] Božik M, P. Nový P, Klouček P. Susceptibility of postharvest pathogens to essential oils. Scientia Agriculturae Bohemica 2017;48(3):103-11.

[61] Diánez F, Santos M, Parra C, Navarro MJ, Blanco R, Gea FJ. Screening of antifungal activity of 12 essential oils against eight pathogenic fungi of vegetables and mushroom. Lett Appl Microbiol. 2018;67(4):400-10.

[62] Park JY, Jim SH, Kim NH, Lee SW, Jeun YC, Hong JK. Differential inhibitory activities of four plant essential oils on in vitro growth of Fusarium oxysporum f. sp. fragariae causing fusarium wilt in strawberry plants. Plant Pathol J. 2017;33(6):582-8.

[63] Riccioni L, Orzali L. Activity of tea tree (Melaleuca alternifolia, Cheel) and thyme (Thymus vulgaris, Linnaeus.) essential oils against some pathogenic seed borne fungi. J Essent Oil Res. 2011;23(6):43-7.

[64] Kong Q, Zhang L, An P, Qi J, Yu X, Lu J, et al. Antifungal mechanisms of $\alpha$-terpineol and terpene-4-alcohol as the critical components of Melaleuca alternifolia oil in the inhibition of rot disease caused by Aspergillus ochraceus in postharvest grapes. J Appl Microbiol. 2019;126(4):1161-74.

[65] Hussein KA, Joo JH. Antifungal activity and chemical composition of ginger essential oil against ginseng pathogenic fungi. Curr Res Environ Appl Mycol. 2018;8(2):194-203.

[66] Santamaria MP, Ibáñez MD, Marqués M, Roselló J, Gímenez S, Blázquez MA. Bioactivity of essential oils in phytopathogenic and post-harvest fungi control. Nat Prod Res. 2017;32(22): 2675-9. 
